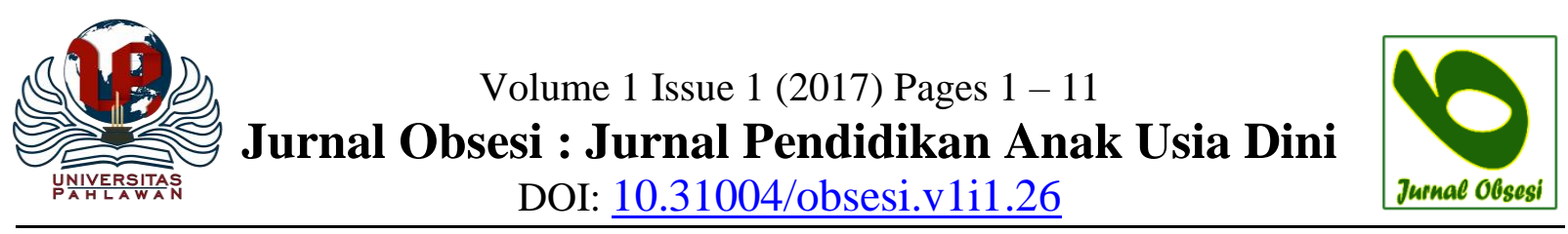

\title{
Analisis Penggunaan Gadget terhadap Kemampuan Interaksi Sosial pada Anak Usia Dini
}

\author{
Putri Hana Pebriana ${ }^{凶}$ \\ Prodi PGSD, FIP, Universitas Pahlawan Tuanku Tambusai
}

\begin{abstract}
ABSTRAK
Perkembangan teknologi semakin canggih dan berkembang. Hal ini menyebabkan berbagai pengaruh pola hidup manusia baik pola pikir maupun perilaku. Salah satu perkembangan teknologi yang mempengaruhi pikiran manusia adalah gadget. Gadget adalah media yang digunakan sebagai sarana komunikasi modern. Gadget tidak hanya mempengaruhi pola pikir atau perilaku orang dewasa, tapi juga mempengaruhi tingkah laku anak usia dini. Intinya, anak usia dini cenderung senang dengan halhal baru yang ia dapatkan melalui aktivitas dengan bermain. Bermain sangat menyenangkan bagi anak-anak, dengan bermain anak bisa menggali semua potensi. Mayoritas anak di Indonesia menghabiskan waktu bermain dengan gadget. Tentunya ini mempengaruhi perkembangan anak, terutama dalam pengembangan interaksi sosial. Interaksi sosial dapat diartikan sebagai hubungan yang terjadi dalam kelompok induvidu yang saling berhubungan baik dalam komunikasi maupun aksi sosial. Tujuan penelitian ini untuk mendeskripsikan penggunaan gadget terhadap kemampuan interaksi sosial anak usia dini. Adapun metode penelitian yang digunakan dalam penelitian ini adalah kajian pustaka yaitu dengan menghubungkan penelitian dengan literatur yang ada dan mengisi celah dalam penelitian sebelumnya. Hasil penelitian yang diperoleh pada penelitian ini yaitu penggunaan gadget kebanyakan anak lebih menggunakannya untuk bermain. Dari hal kecil tersebut, anak yang awalnya senang bermain dengan temannya dapat berubah dengan terbiasanya diberikan gadget sebagai pengganti teman bermain.
\end{abstract}

\section{Kata Kunci: Gadget, Interaksi Sosial}

\section{ABSTRACT}

Technological developments increasingly sophisticated and growing. This leads to various influences of human lifestyle both mindset and behavior. One of the technological developments that affect the human mind is the gadget. Gadgets are media used as a means of modern communication. Gadgets not only affect the mindset or behavior of adults, but also affect the behavior of young children. In essence, early childhood tend to be happy with new things that he got through the activity by playing. Playing is fun for the kids, with children's play can explore all the potential. The majority of children in Indonesia spend time playing with gadgets. Surely this affects the development of children, especially in the development of social interaction. Social interactions can be interpreted as relationships that occur within induvidu groups are interconnected both in communication and social action. The purpose of this study to describe the use of gadgets to the ability of social interaction of early childhood. The research method used in this study is literature review is by connecting research with existing literature and fill the gap in previous research. The results obtained in this study is the use of gadgets most children use it to play. From these small things, children who initially love to play with their friends can change with the usual given a gadget as a substitute for playmates.

\section{Keywords : Gadget, Social Interaction}

@Jurnal Obsesi Prodi PG-PAUD FIK UPTT 2017

$\triangle$ Corresponding author :

Address : Perum Attaya Ridan Permai Bangkinang Kampar

Email : putripebriana99@gmail.com

ISSN 2356-1327 (Media Cetak) ISSN 2549-8959 (Media Online) 


\section{PENDAHULUAN}

Perkembangan teknologi semakin berkembang dengan pesat sesuai dengan perkembangan zaman.Teknologi muncul berbagai macam jenis dan fitur dari teknologi selalu baru dari hari ke hari. Kebutuhan teknologi merupakan salah satu kebutuhan penting saat ini. Hal ini disebabkan karena teknologi sangat dibutuhkan untuk keperluan banyak. Teknologi sangat mudah didapatkan karena harga ada yang murah dan ada juga yang mahal sesuai dengan kantong ekonomi penggunanya.

Gagdet merupakan salah satu bentuk nyata dari berkembangnya Ipteks pada zaman sekarang. Tentunya dengan berkembangnya Ipteks, hal ini sangat mempengaruhi pola kehidupan manusia baik dari segi pola pikir maupun perilaku. Tentunya dengan bantuan teknologi seperti gadget dapat mempermudah kegiatan manusia agar tidak memakan waktu yang lama. Selain itu, penggunaan gadget dalam kehidupan sehari-hari tidak hanya mempengaruhi perilaku orang dewasa, anak-anak pun tidak luput dari pengaruh penggunaan gagdet salah satunya dalam kemampuan interaksi sosial.

Pendidikan anak usia dini adalah anak yang berusia 0-6 tahun, pendidikan anak usiadini memiliki peranan yang sangat penting untuk mengembangkan kepribadian anak serta mempersiapkan anak untuk memasuki jenjang pendidikan yang lebih lanjut (Fauziddin, 2016)

Anak usia dini adalah anak yang berada pada usia 0-8 tahun. Menurut Beichler dan Snowman (Dwi Yulianti, 2010:7), anak usia dini adalah anak yang berusia antara 3-6 tahun. Sedangkan hakikat anak usia dini (Augusta, 2012) adalah individu yang unik dimana ia memiliki pola pertumbuhan dan perkembangan dalam aspek fisik, kognitif, sosioemosional, kreativitas, bahasa dan komunikasi yang khusus yang sesuai dengan tahapan yang sedang dilalui oleh anak tersebut. Masa anak usia dini sering disebut dengan istilah "golden age" atau masa emas. Pada masa ini hampir seluruh potensi anak mengalami masa peka untuk tumbuh dan berkembang secara cepat dan hebat. Perkembangan setiap anak tidak sama karena setiap individu memiliki perkembangan yang berbeda.

Pada anak usia dini ini, anak mengalami perkembangan dalam tahap mengeksplor dan berinteraksi langsung dengan lingkungan sekitarnya. Anak usia dini biasanya cenderung senang dengan hal-hal yang baru yang didapatnya melalui aktivitas bermain. Tidak jarang pula anak bermain dan memuaskan rasa penasaran mereka melalui gadget, karena gadget merupakan hal yang menarik bagi mereka apalagi ditambah dengan aplikasi game online yang terdapat pada gadget, sehingga kebanyakan dari mereka menghabiskan waktu seharian untuk bermain gadget. Padahal anak seusia mereka harus bermain dan berbaur dengan teman-teman sebayanya.

Tidak dapat dipungkiri, gadget sangat mempengaruhi kehidupan manusia, baik orang dewasa maupun anak-anak. Smartphone, notebook, tablet dan aneka ragam bentuk gadget dalam kehidupan sehari-hari sangat mudah ditemui pada zaman sekarang. Hal seperti ini bukan menjadi hal yang mewah untuk zaman sekarang, karena sebagian dari anak-anak sudah difasilitasi oleh orang tuanya sendiri agar orang tua lebih leluasa untuk melakukan aktivitas tanpa harus mendampingi anak bermain. Anak-anak tentunya sangat senang jika memperoleh gadget dari orang tuanya. Namun tanpa disadari, hal seperti ini sangat mempengaruhi kemampuan interaksi sosial pada anak. 


\section{Gadget}

Gadget adalah media yang dipakai sebagai alat komunikasi modern. Gadget semakin mempermudah kegiatan komunikasi manusia. Kini kegiatan komunikasi telah berkembang semakin lebih maju dengan munculnya gadget. Gadget adalah perangkat elektronik kecil yang memiliki fungsi khusus. Diantaranya martphone seperti iphone dan blackberry, serta netbook (perpaduan antara komputer portabel seperti notebook dan internet). Novitasari (2016) menyatakan bahwa media memungkinkan seseorang untuk melakukan sebuah interaksi sosial, khususnya untuk kontak sosial maupun berkomunikasi satu dengan yang lainnya tidaklah susah, hanya dengan menggunakan gadget seseorang dapat berinteraksi satu dengan lainnya. Gadget menurut kamus berarti perangkat elektronik kecil yang memiliki fungsi khusus. Gadget merujuk pada suatu peranti atau instrument kecil yang memiliki tujuan dan fungsi praktis spesifik yang berguna (Castelluccio, Michael. 2007).

A gadget is a smalltechnological object (such as a device or an appliance) that has a particular function, but is often thought of as a novelty. Gadgets are invariably considered to be more unusually or cleverly designed than normal technology at the time of their invention. Gadgets are sometimes also referred to as gizmos. (Wikipedia.com)

Pada dasarnya, gadget diciptakan untuk kemudahan konsumen dalam menggunakan media komunikasi. Definisi komunikasi menurut Laswell (West dan Turner. 2007:30-31) adalah suatu proses yang menjelaskan siapa, mengatakan apa, dengan saluran apa, kepada siapa, dengan akibat atau hasil apa, gadget jika dilihat melalui model komunikasi Laswell, merupakan media dalam menyampaikan pesan antara komunikator dan komunikan. Dapat disimpulkan bahwa gadget merupakan salah satu media untuk berkomunikasi dengan tujuan untuk mempermudah kegiatan komunikasi manusia.

\section{Anak Usia Dini}

Di Indonesia pengertian anak usia dini ditujukan kepada anak yang berusia 06 tahun, seperti dalam Undang-undang Republik Indonesia Nomor 20 tahun 2003 tentang Sistem Pendidikan Nasional pada Pasal 1 ayat 14 yang menyatakan pendidikan anak usia dini adalah pendidikan yang diperuntukkan bagi anak sejak lahir sampai usia 6 tahun. Sedangkan Anak usia dini menurut NAEYC (National Association for The Education of Young Children), adalah anak yang berusia antara 0 sampai 8 tahun yang mendapatkan layanan pendidikan di taman penitipan anak, penitipan anak dalam keluarga (family child care home), pendidikan prasekolah baik negeri maupun swasta, taman kanak-kanak (TK) dan sekolah dasar (SD). Hal ini dapat disebabkan pendekatan pada kelas awal sekolah dasar kelas I, II dan III hampir sama dengan usia TK 4-6 tahun.

Usia dini merupakan masa emas, masa ketika anak mengalami pertumbuhan dan perkembangan yang pesat. Pada usia ini anak paling peka dan potensial untuk mempelajari sesuatu, rasa ingin tahu anak sangat besar. Hal ini dapat kita lihat dari anak sering bertanya tentang apa yang mereka lihat. Apabila pertanyaan anak belum terjawab, maka mereka akan terus bertanya sampai anak mengetahui maksudnya. Di samping itu, setiap anak memiliki keunikan sendiri-sendiri yang berasal dari faktor genetik atau bisa juga dari faktor lingkungan. Faktor genetik misalnya dalam hal kecerdasan anak, 
sedangkan faktor lingkungan bisa dalam hal gaya belajar anak.

Hakikat anak usia dini (Augusta, 2012) adalah individu yang unik dimana ia memiliki pola pertumbuhan dan perkembangan dalam aspek fisik, kognitif, sosioemosional, kreativitas, bahasa dan komunikasi yang khusus yang sesuai dengan tahapan yang sedang dilalui oleh anak tersebut. Dari berbagai definisi, peneliti menyimpulkan bahwa anak usia dini adalah anak yang berusia 0-8 tahun yang sedang dalam tahap pertumbuhan dan perkembangan, baik fisik maupun mental.

Anak usia dini merupakan masa peka dalam berbagai aspek perkembangan yaitu masa awal pengembangan kemampuan fisik motorik, bahasa, sosial emosional, serta kognitif. Menurut Piaget (Slamet Suyanto, 2003: 56-72), anak memiliki 4 tingkat perkembangan kognitif yaitu tahapan sensori motorik (0-2 tahun), pra operasional konkrit (2-7 tahun), operasional konkrit (7-11 tahun), dan operasional formal (11 tahun ke atas). Karakteristik anak usia dini merupakan individu yang memiliki tingkat perkembangan yang relatif cepat merespon (menangkap) segala sesuatu dari berbagai aspek perkembangan yang ada. Sedangkan karakteristik anak usia dini menurut Richard D.Kellough (Kuntjojo, 2010) adalah sebagai berikut: a) egosentris, b) memiliki curiosity yang tinggi, c) makhluk sosial, d) the unique person, e) kaya dengan fantasi, f) daya konsentrasi yang pendek, g) masa belajar yang paling potensial.

Anak-anak yang berada pada masa prasekolah berada pada periode yang sensitif, ia mudah menerima rangsanganrangsangan dari lingkungan. Menurut Hainstok dalam Sujiono (2009:54) pada masa ini anak mulai peka untuk menerima berbagai stimulasi dan upaya pendidikan dari lingkungan baik disengaja atau tidak.
Pada masa ini pula terjadi pematangan fungsi-fungsi fisik dan psikis sehingga anak siap merespon dan mengaktualisasikan tahapan perkembangan pada prilakunya sehari hari.

Wiyani (2012:86) mengungkap prinsip-prinsip perkembangan anak, meliput;. a) anak berkembang secara holistik, b) perkembangan terjadi dalam urutan yang teratur, c) perkembangan anak berlangsung pada tingkat yang beragam didalam dan diantara anak, d) perkembangan baru didasarkan pada perkembangan sebelumnya dan e) perkembangan mempunyai pengaruh yang bersifat kumulatif. Sedangkan Aqib (2011:75) mengutarakan prisip-prinsip perkembangan sebagai berikut; a) anak belajar dengan baik jika kebutuhan fisiknya terpenuhi, b) anak belajar secara terus menerus, membangun pemahaman hingga mencipta sesuatu, c) anak belajar melalui interaksi sosial, d) motivasi timbul dari minat dan ketekunan, e) adanya perbedaan dan dalam gaya belajar dan f) memulai dari yang sederhana kekompleks, konkret ke abstrak, gerakan ke verbal dan dari diri kesosial.

\section{Interaksi Sosial}

Kata interaksi secara umum dapat diartikan saling berhubungan atau saling bereaksi dan terjadi pada dua orang induvidu atau lebih. Sedangkan sosial adalah berkenaan dengan masyarakat (Wiyono, 2007:234). Oleh karena itu secara umum interaksi sosial dapat diartikan sebagai hubungan yang terjadi dalam sekelompok induvidu yang saling berhubungan baik dalam berkomunikasi maupun melakukan tindakan sosial.

Interaksi sosial merupakan pula salah satu prinsip integritas kurikulum pembelajaran yang meliputi keterampilan berkomunikasi, yang bekerja sama yang dapat untuk menumbuhkan komunikasi 
yang harmonis antara individu dengan lingkungannya (Hernawan, 2010:314).

(Max Weber dalam Hernawan, 2010:14), menjelaskan bahwa tindakan interaksi sosial adalah tindakan seorang individu yang dapat mempengaruhi individu-individu lainnya dalam lingkungan sosial. Dalam bertindak atau berperilaku sosial, seorang individu hendaknya memperhitungkan keberadaan individu lain yang ada dalam lingkungannya. Hal tersebut penting diperhatikan karena tindakan interaksi sosial merupakan perwujudan dari hubungan atau interaksi sosial. Dapat disimpulkan bahwa interaksi sosial adalah hubungan atau komunikasi yang dilakukan oleh dua orang atau lebih dengan tujuan untuk saling mempengaruhi satu dengan yang lainnya untuk mencapai tujuan tertentu, dalam hal ini dapat diartikan bahwa dalam interaksi sosial terdapat dalam hubungan antar individu, kelompok, yang merupakan hubungan yang dilakukan oleh manusia untuk bertindak terhadap sesuatu atas dasar makna yang dimiliki oleh manusia.

Perkembangan perilaku sosial anak ditandai dengan adanya minat terhadap aktivitas teman-teman dan meningkatnya keinginan yang kuat untuk diterima sebagai anggota suatu kelompok, dan tidak puas bila tidak bersama teman-temannya. Anak tidak lagi puas bermain sendiri dirumah atau dengan saudara-saudara kandung atau melakukan kegiatan-kegiatan dengan anggota-anggota keluarga. Anak ingin bersama teman-temannya dan akan merasa kesepian serta tidak puas bila tidak bersama teman-temannya.

Menurut Hurlock (1998) factor yang mempengaruhi perkembangan sosial anak yaitu :
1. Keluarga

a. Hubungan antar orang tua, antar saudara antar anak dengan orang tua.Hubungan anak dengan orangtua ataupun saudara akan terjalin rasa kasih sayang, dimana anak akan lebih terbuka dalam melakukan interaksi karena terjalinnya hubungan yang baik yang di tunjang oleh komunikasi yang tepat. Peran orang tua akan membimbing sang anak untuk mengenal lingkungan sekitar tempat tinggalnya.

b. Urutan anak dalam keluarga (sulung/tengah/bungsu)

Urutan posisi anak dalam keluarga berpengaruh pada anak misalnya sang anak merupakan anak terakhir maka dipastikan sang anak selalu bergantung pada orangtua dan saudaranya. Jika hal ini terjadi akan berpengaruh pada tingkat kemandirian anak tersebut.

c. Jumlah keluarga

Pada dasarnya jumlah anggota yang besar berbeda dengan jumlah anggota yang sedikit, maka perhatian, waktu dan kasih saying lebih banyak tercurahkan, dimana segala bentuk aktifitas dapat ditemani ataupun dibantu. Hal ii berbeda dengan anak dengan keluarga yang besar.

d. Perlakuan keluarga terhadap anak Adanya perlakuan keluarga terhadap anak prasekolah secara langsung mempengaruhi pribadi dan gerakan sang anak, dimana dalam keluarga tertanam rasa saling perhatian, tidak kasar dan selalu merespon setiap kegiatan anak, maka dapat berpengaruh terhadap perkembangan anak yang lebih baik dan terarah.

e. Harapan orang tua terhadap anak

Setiap orangtua memiliki harapan mempunyai anak yang baik, cerdas 
dan terarah dalam masa depannya. Harapan orangtua adalah mempunyai anak yang memilikiperkembangan sesuai dengan pertumbuhannya. Artinya bahwa perkembangan anak pra sekolah yang sekolah bertujuan mempunyai arah sesuai perkembangannya.

2. Factor diluar keluarga

a. Interaksi dengan teman sebaya

Setiap anak jika mempunyai perkembangan yang baik, maka secara alami dapat berinteraksi dengan temannya tanpa harus disuruh atau dditemani keluarga karena anak memiliki arahan yang jelas.

b. Hubungan dengan orang dewasa diluar rumah

Jika seorang anak selalu bergaul dengan siapa saja maka sang anak dapat menyesuaikan lingkungan orang dewasa dimana anak tanpa malu-malu berinteraksi dengan orang yang lebih dewasa darinya.

c. Kemampuan untuk dapat diterima dikelompok

Anak-anak yang populer dan melihat kemungkinan memperoleh penerimaan kelompok lebih di pengaruhi kelompok, kurang di pengaruhi keluarga dibandingkan hubungan anak-anak yang pergaulannya dengan kelompok tidak begitu akrab. Anak-anak yang hanya melihat adanya kesempatan kecil untuk dapat diterima kelompok mempunyai motivasi kecil pula untuk menyesuaikan diri dengan standar kelompok

d. Keamanan karena status dalam kelompok

Anak-anak yang merasa aman dalam kelompok akan lebih bebas dalam mengekspresikan ketidak cocokan mereka dengan pendapat anggota lainnya. Sebaliknya, mereka yang merasa tidak aman akan menyesuikan diri sebaik mungkin dan mengukuti anggota lainnya.

e. Tipe kelompok

Pengaruh kelompok berasal dari jarak sosial yaitu derajat hubungan kasih sayang diantara para anggota kelompok. Pada kelompok primer ( antara lain keluarga atau kelompok teman sebaya) ikatan hubungan dalam kelompok lebih kuat dibandingkan dengan pada kelompok sekunder (antara lain kelompok bermain yang diorganisasikan atau perkumpulan sosial) atau pada kelompok tertier ( antara lain orangorang yang berhubungan dengan anak minsalnya di dalam bus)

f. Perbedaan keanggotaan dalam kelompok

Dalam sebuah kelompok, pengaruh terbesar biasanya timbul dari pemimpin kelompok dan pengaruh yang terkecil berasal dari anggota yang paling tidak populer.

g. Kepribadiaan

Anak-anak yang merasa tak mampu atau rendah diri lebih banyak dipengaruhi oleh kelompok di bandingkan dengan mereka yang memiliki kepercayaan pada diri sendiri yang besar dan yang lebih menerima diri sendiri.

h. Motif menggabungkan diri

Semakin kuat motif anak-anak untuk menggabungkan diri ( affilation motive) yaitu, keinginan untuk diterima, semakin rentan mereka terhadap pengaruh anggota lainnya, terutama pengaruh dari mereka yang mempunyai status tinggi dalam kelompok. 


\section{Karakteristik Interaksi Sosial}

Menurut (Gerungan, 2010:14) bahwa interaksi sosial itu memiliki karakteristik yang dinamis dan tidak statis. Hal ini berarti bahwa karakteritik interaksi sosial dapat ditinjau dari berbagai segi sesuai dengan ciri interaksi yang dilakukan manusia. Artinya bahwa karakteritik interkasi akan dapat dilihat secara detail pada model interaksi yang dilakukan oleh manusia. Secara umum model karakteristik interaksi sosial dapat diartikan sebagaimodel interaksi sosial yang secara induvidu,secara kelompok serta kelompok dengan kelompok. Untuk kejelasan karakteristik tersebut maka peneliti akan menguraikan karakteristik interaksi sosial sebagai berikut:

1. Interaksi antara individu dengan individu

Interaksi ini terjadi karena hubungan masing-masing personil atau individu. Perwujudan dari interaksi ini terlihat dalam bentuk komunikasi lisan atau gerak tubuh, seperti berjabat tangan, saling menegur, bercakap-cakap, atau saling bertengkar.

2. Interaksi Antara Individu dengan Kelompok

Bentuk interaksi ini terjadi antara individu dengan kelompok. Individu memiliki kepentingan untuk berinteraksi dengan kelompok tersebut. Misalnya seorang guru memiliki hubungan dengan individuatau siswa di sekolah. Bentuk interaksi semacam ini juga menunjukkan bahwa kepentingan seseorang individu berhadapan dengan kepentingan kelompok.

3. Interaksi Antara Kelompok dengan Kelompok

Jenis interaksi ini saling berhadapan dalam bentuk berkomunikasi,namun bisa juga ada kepentingan individu di dalamnya atau kepentingan individu dalam kelompok tersebut.Ini merupakan satu kesatuan yang berhubungan dengan kepentingan individu dalam kelompok yang lain.

\section{Bentuk-bentuk Interaksi Sosial}

Menurut (Gerungan, 2010:194) bahwa sesuai dengan bentuk pelaksanaannya terdapat jenis interaksi sosial yaitu. Guna dalam menjelaskan bentuk interaksi sosial tersebut akan diuraikan sebagai berikut:

1. Interaksi Antar status

Interaksi antar status adalah hubungan antara dua pihak dalam individu yang berbeda dalam satu lingkungan yang bersifat formal sehingga masingmasing pihak dapat melakukan interaksinya didasarkan pada status masing-masing. Misalnya hubungan antara guru dan siswa atau siswa dengan orang tua atau dengan keluarganya yang berbeda status.

2. Interaksi Antar kepentingan

Interaksi antara kepentingan merupakan hubungan antara pihak induvidu yang berorientasi terhadap kepentingan dari masing-masing pihak. Dalam hubungan ini, masing-masing pihak saling memberikan solidaritasnya untuk mendukung terciptanya suatu sikap yang harmonis sehingga komunikasi tersebut dapat tercapai dengan baik.

3. Interaksi antara Keluarga

Interaksi antar keluarga merupakan suatu hubungan yang terjadi antar pihak yang mempunyai hubungan darah. Pada hubungan ini,solidaritas antara anggota yang relatif lebih tinggi dan bentuk hubungannya lebih bersifat informal.

4. Interaksi antar Persahabatan

Interaksi ini merupakan hubungan antara dua atau lebih dimana masing- 
masing individu sangat mendambakan adanya komunikasi yang saling menguntungkan untuk menjalin suatu hubungan yang sedemikian dekat atau kekerabatan.

\section{METODOLOGI PENELITIAN}

Penelitian ini menggunakan kajian pustaka, kajian pustaka dalam suatu penelitian ilmiah adalah salah satu bagian penting dari keseluruhan langkah-langkah metode penelitian. Cooper dalam Creswell mengemukakan bahwa kajian pustaka memiliki beberapa tujuan yakni; menginformasikan kepada pembaca hasilhasil penelitian lain yang berkaitan erat dengan penelitian yang dilakukan saat itu, menghubungkan penelitian dengan literatur-literatur yang ada, dan mengisi celah-celah dalam penelitian-penelitian sebelumnya. Geoffrey dan Airasian mengemukakan bahwa tujuan utama kajian pustaka adalah untuk menentukan apa yang telah dilakukan orang yang berhubungan dengan topik penelitian yang akan dilakukan. Dengan mengkaji penelitian sebelumnya, dapat memberikan alasan untuk hipotesis penelitian, sekaligus menjadi indikasi pembenaran pentingnya penelitian yang akan dilakukan. Lebih lanjut Anderson mengemukakan bahwa kajian pustaka dimaksudkan untuk meringkas, menganalisis, dan menafsirkan konsep dan teori yang berkaitan dengan sebuah proyek penelitian.

\section{HASIL DAN PEMBAHASAN}

Hasil penelitian menunjukan kebanyakan gadget yang diberikan para orang tua kepada anaknya adalah berdasarkan keinginan anaknya. Untuk tujuan tertentu seperti untuk mengenalkan teknologi lebih dini atau sekedar untuk mebuat anaknya tidak bosan. Bagi orang tua yang seperti ini lebih beranggapan bahwa dengan gadget anak usia dini dapat memperluas jaringan persahabatan mereka karena dapat dengan mudah dan cepat bergabung ke sosial media yang telah disediakan (Nurrachmawati, 2014). Terkadang juga gadget dapat dijadikan para orang tua untuk mengalihkan anakanak agar tidak mengganggu pekerjaan oarang tuanya sehingga para orang tua menyediakan fasilitas berupa gadget untuk anaknya yang masih berusia dini (Widiawati \& Sugiman, 2014).

Pada salah satu penelitian oleh Novitasari (2016) penggunaan gadget pada anak usia dini menyebutkan bahwa "pemakaian gadget lebih menyenangkan dibandingkan dengan bermain dengan teman sebayanya. Hal ini tak lepas oleh berbagai aplikasi permainan yang terdapat pada gadget anak-anak ini, yang tentunya lebih menarik perhatian anak-anak ini dibandingkan dengan permainan-permaian yang terdapat di lingkungan sekitarnya. Selain itu juga, orangtua meng"iya"kan bahwa saat anak-anaknya bermain gadget cenderung anak-anak ini diam di depan gadgetnya masing-masing tanpa mempedulikan dunia sekitarnya". Secara tidak sadar, anak-anak sudah mengalami ketergantungan menggunakan gadget. Ketergantungan inilah yang menjadi salah satu dampak negatif yang sangat berpengaruh (Prasetyo, 2013). Para responder menyebutkan bahwa dalam penggunaan gadget kebanyakan anak lebih menggunakannya untuk bermain. Dari hal kecil tersebut, anak yang awalnya senang bermain dengan temannya dapat berubah dengan terbiasanya diberikan gadget sebagai pengganti teman bermain.

Kertergantungan terhadap gadget pada anak disebabkan karena lamanya durasi dalam menggunakan gadget. Bermain gadget dengan durasi yang cukup panjang dan dilakukan setiap hari, bisa membuat anak berkembang ke arah pribadi yang antisosial. Dampak yang ditimbulkan 
dari hal itu sebenarnya adalah dapat membuat anak lebih bersikap individualis karena lama kelamaan menyebabkan lupa berkomunikasi dan berinteraksi terhadap lingkungan di sekitarnya (Simamora, 2016).

Hal tersebut dapat menyebabkan interaksi sosial antara anak dengan masyarakat, lingkungan sekitar berkurang, bahkan semakin luntur (Ismanto dan Onibala, 2015). Seperti yang diketahui bahwa usia dini merupakan usia anak dapat mengasah kemampuan bersosialisasinya dengan baik dilingkungan sosial. Namun, dari penelitian yang dilakukan terhadap responder menyatakan bahwa dalam penggunaan gadget selalu dibatasi durasinya dan selalu dilakukan pengawasan sehingga hal tersebut tidak terjadi.

Menurut Maulida (2013) Tandatanda anak usia dini kecanduan gadget:
1. Kehilangan keinginan untuk beraktivitas;

2. Berbicara tentang teknologi secara terus menerus;

3. Cenderung sering membantah suatu perintah jika itu menghalangi dirinya mengakses gadget;

4. Sensitif atau gampang tersinggung, menyebabkan mood yang mudah berubah;

5. Egois, sulit berbagi waktu dalam penggunaan gadget dengan orang lain;

6. Sering berbohong karena sudah tidak bisa lepas dengan gadgetnya, dengan kata lain anak akan mencari cara apapun agar tetap bisa menggunakan gadgetnya walaupun hingga mengganggu waktu tidurnya.

Dari ciri-ciri tersebut, dapat dilihat ternyata penggunaan gadget pada anak usia dini dapat mengurangi interaksi sosialnya dalam kehidupan sehari-hari baik itu dengan orang tuanya, teman sebanya, maupun dengan masyarakat. Untuk itu, ada baiknya orang tua perlu mendampingi dan membimbing anaknya saat sedang menggunakan gadget, dan peran orang tua dalam mendisiplinkan sangat dibutuhkan agar anak tidak mengalami ketergantungan yang akan menyebabkan dampak negatif terhadap perkembangan anak terutamadengan hubugannya dengan kehidupan sosial anak tersebut (Ameliola, 2013)

\section{KESIMPULAN}

Hal ini menyebabkan berbagai macam pengaruh terhadap pola kehidupan manusia baik pola pikir maupun perilaku. Teknologi adalah keseluruhan sarana untuk menyediakan barang-barang yang diperlukan bagi kelangsungan dan kenyamanan hidup manusia. Salah satu perkembangan teknologi yang sangat mempengaruhi pola pikir manusia adalah gadget. Gadget adalah media yang dipakai sebagai alat komunikasi modern. Gadget semakin mempermudah kegiatan komunikasi manusia. Kini kegiatan komunikasi telah berkembang semakin lebih maju dengan munculnya gadget. Salah satunya mempengaruhi interaksi sosial pada anak usia dini.

Interaksi sosial berasal dari istilah dalam bahasa Inggris social interaction yang berarti saling bertindak. Interaksi sosial merupakan hubungan sosial yang dinamis, bersifat timbal balik antarindividu, antarkelompok, dan antara individu dengan kelompok. Interaksi sosial terjadi apabila satu individu melakukan tindakan sehingga menimbulkan reaksi bagi individu-individu lain. Interaksi sosial tidak hanya berupa tindakan yang berupa kerja sama, tetapi juga bisa berupa persaingan dan pertikaian.

Berkaitan dengan pengaruh gadget terhadap interaksi sosial pada anak usia 
10 | Analisis Penggunaan Gadget terhadap Kemampuan Interaksi Sosial Anak Usia Dini

dini ternyata memberikan dampak negatif. Seringnya anak usia dini berinteraksi dengan gadget dan juga dunia maya mempengaruhi daya pikir anak terhadap sesuatu diluar hal tersebut. Gadget juga ternyata secara efektif dapat mempengaruhi pergaulan sosial anak terhadap lingkungan terdekatnya. Selain itu, ia juga akan merasa asing dengan lingkungan sekitar karena kurangnya interaksi sosial selain itu anak juga kurang peka dan bahkan cenderung tidak perduli terhadap lingkungannya.

Hal ini tentunya sangat membahayakan perkembangan sosial pada anak usia dini. Sebagai orang tua, sebaiknya mereka membimbing dan memantau serta memberikan pemahaman yang baik kepada anak untuk lebih selektif dalam memilih permainan (game online) yang terdapat pada gadget.

\section{UCAPAN TERIMA KASIH}

Ucapan terima kasih disampaikan kepada civitas akademika Universitas Pahlawan Tuanku Tambusai dan semua pihak yang telah membantu dalam proses penelitian dan pembuatan artikel ini.

\section{DAFTAR PUSTAKA}

Ameliola, Nugraha. 2013. Perkembangan Media Informasi dan Teknologi Terhadap Anak dalam Era Globalisasi. [Online] Diakses dari http://icssis.files.wordpress.com/ $\underline{2013 / 09 / 2}$ 013-0229 pada tanggal 26 Desember 2016.

Castelluccio, Michael. 2007. Gadget AnEssay.

http://www.thefreelibrary.com/Gadgets- an+essay.-a0170115914 diakses pada 9 Juli 2014

Cvano, Osland. 2013. Pengertian Gadget. [Online] diakses di laman http://mencobacariduit.blo gpot.com/2013/09/pengertian- gadget.html / 2013/ pada 27

Desember 2016

Fauziddin, 2016. Penerapan Belajar Melalui Bermain Balok Unit Untuk Meningkatkan Kreativitas Anak Usia Dini. Jurnal Curicula. Vol 1 No 3

Hurlock, B. Elizabeth. 1978. Perkembangan Anak. Jakarta: Erlangga

Ismanto, Yudi \& Onibala, Franly. 2015. Hubungan Penggunaan Gadget Dengan Tingkat Prestasi Siswa Di Sma Negeri 9 Manado. Ejoural Keperawata Volume 3(2). Manado: FK Unsrat Manando

Maulida, Hidayahti. 2013. Menelisik Pengaruh Penggunaan Aplikasi Gadget Terhadap Perkembang an Psikologis Anak Usia Dini. Jurnal Ilmiah Teknologi Pendidikan 2013. Semarang: FKIP Universitas Negeri Semarang

Mukti, Fajar dan Yulianto Ahmad. 2010. Dualism Penelitian Hukum Normatif dan Empiris. Yogyakarta: Pustaka Pelajar.

Novitasari, Wahyu. 2016. Dampak Penggunaan Gadget Terhadap Interaksi Sosial Anak Usia 5-6 Tahun. Surabaya: UNS

Nurrachmawati, 2014. Pengaruh sistem operasi mobile android pada anak usia dini. Jurnal pengaruh system operasi mobile android pada anak usia dini. Jurnal Pengaruh Sistem Operasi Mobile Android Pada Anak Usia Dini. $\quad$ Makasar: FT Universitas Hasanuddin.

Prasetyo, Eko. 2013. Gadget. [Online] Diakses pada laman http://epzna.blogspot.com/2013/08/gadg et.html pada 27 Desember 2016.

Prianggoro, Hasto. 2014. Anak dan Gadget: Yang Penting Aturan Main. [Online] Diakses dari http://www.tabloidnakita.com/read/1/an ak-dan-gadget- yangpenting-aturanmain pada tanggal 26 Oktober 2016. 
Simamora, Antonius SM. 2016. Persepsi Orangtua Terhadap Dampak Penggunaan Gadget Pada Anak Usia Pendidikan Dasar Di Perumahan Bukit Kemiling Permai Kecamatan Kemiling Bandar Lampung. Lampung: Universitas Lampung.

Soekanto, Soerjono. 1992. Sosiologi Suatu Pengantar. Jakarta: Rajawali

West, Richard dan Lynn Turner. 2007. Introduction Communication Theory. Analysis and Application. New York: McGraw Hill.

Widiawati \& Sugiman. 2014. Pengaruh Penggunaan Gadget Terhadap Daya Kembang Anak. [Online] Diakses dari laman http://stmikglobal.ac.id/wpcon tent/uploads/2014/05/ARTIKELIIS.pd pada tanggal 26 Desember 2016 